\title{
What is a "case"?
}

OÑATi SOCiO-Legal Series Volume 11, Issue 2 (2021), 354-377: “TOO MUCH LiTigation?”: FACTS, REASONS, CONSEQUENCES, AND SOLUTIONS

DOI LINK: HTTPS://DOI.ORG/10.35295/OSLS.IISL/0000-0000-0000-1149

RECEIVED 16 SEPTEMBER 2020, ACCEPTED 12 JANUARY 2021

\section{LYNN MATHER* (iD)}

\section{Abstract}

This article interrogates the concept of a "case" in court, in an effort to clarify underlying concerns in debates over whether there is "too much" or "too little" litigation. One perspective on litigation takes a bottom-up view, examining the considerations and motives of disputing parties who file civil claims. This perspective includes theories about litigation and social structure, economics, dispute transformation, political participation, and psychology. An alternative top-down view examines litigation from the perspective of government, including its interest in dispute resolution, social control, and institutional capacities of courts. The article reviews and critiques existing literature on these perspectives and concludes with the importance of integrating them.

\section{Key words}

Litigation; case; dispute processing; courts; claims

\section{Resumen}

Este artículo se pregunta por el concepto de "caso" en un tribunal, haciendo un esfuerzo por aclarar preocupaciones subyacentes a los debates sobre si hay "demasiada" o "demasiado poca" litigación. Una perspectiva sobre los litigios va de abajo arriba, examinando las consideraciones y motivos de las partes que interponen una demanda civil. Esa perspectiva abarca teorías sobre el litigio y las estructuras económicas y sociales, la transformación de las disputas, la participación política y la psicología. Una visión alternativa, de arriba abajo, examina los litigios desde la perspectiva del gobierno, tomando también en consideración sus intereses en la resolución de conflictos, el control

\footnotetext{
I am grateful to Barbara Yngvesson and the anonymous reviewers for their helpful comments and suggestions. A conversation with Martin Shapiro decades ago gave me the idea for this paper and I am indebted to him for that and for his encouragement.

* Lynn Mather is SUNY Distinguished Service Professor Emerita of Law and Political Science at University at Buffalo Law School, State University of New York and Research Professor of Justice Studies at University of New Hampshire. Email address: lmather@buffalo.edu. Mail address: 21 Basin Front Drive, Newbury MA 01951 USA.
} 
social y las capacidades institucionales de los tribunales. El artículo revisa y critica literatura existente sobre estas perspectivas, y llega a la conclusión de que es importante integrarlas.

Palabras clave

Litigio; caso; proceso de disputas; tribunales; demandas 


\section{Table of contents}

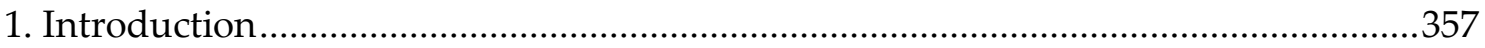

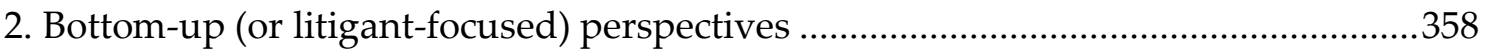

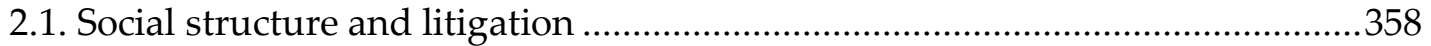

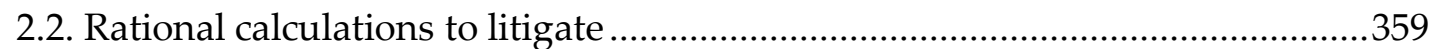

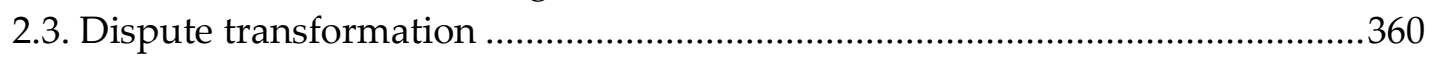

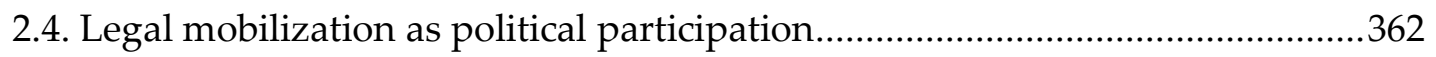

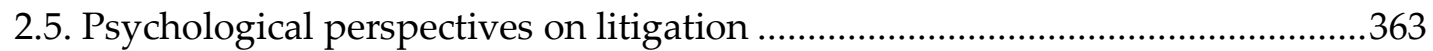

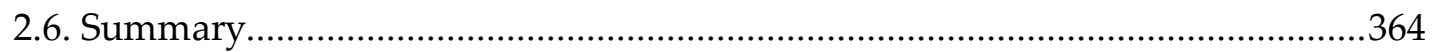

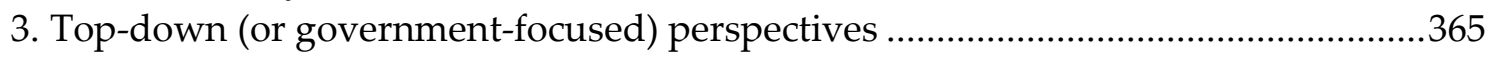

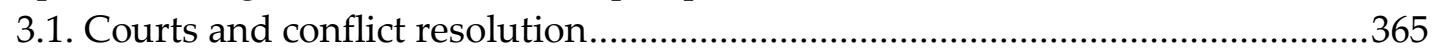

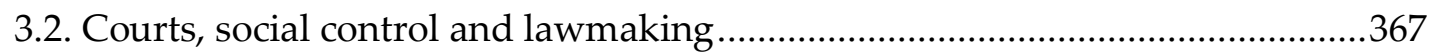

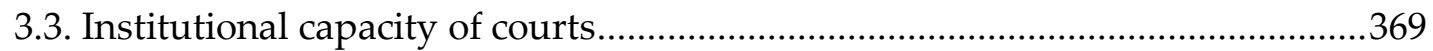

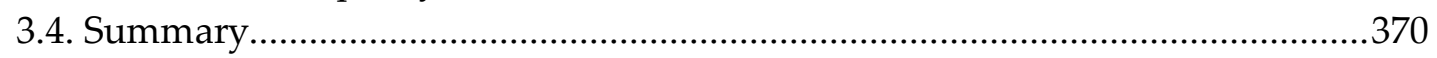

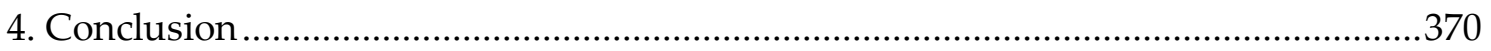

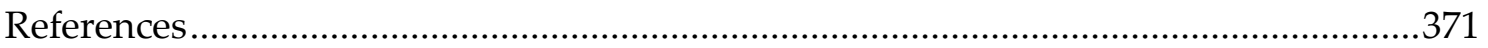

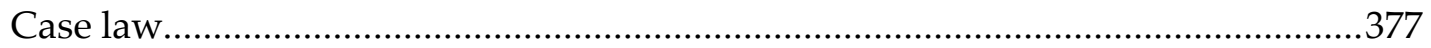




\section{Introduction}

To ask whether there is "too much litigation?" or "too little litigation?" invites comparison, whether by time, by space, or against some objective standard. Historical comparison asks whether there is too much litigation now compared to the past when there was arguably less litigation. Geographical comparison asks whether one country or region has too much litigation as compared to the amount of litigation elsewhere. The notion of an objective standard suggests some "expected" amount of litigation exists that has now been exceeded (litigation explosion) or, alternatively, has not yet been reached (access to justice problem). Each of these comparisons carries an implicit assumption about the basic unit of analysis: the case. This article explores the question - what is a "case" ? - by revisiting earlier socio-legal research on litigation.

In the 1970s-1980s, a large body of theoretical and empirical scholarship investigated litigation in comparative studies that offer important insights into current debates. Why did scholars count the numbers of court cases filed? What did they assume the numbers reflected? "Numbers serve as a language for telling stories" (Stone 2020, p. 22). The stories told by counting cases differ by researchers in sociology, anthropology, economics, and political science. I review the literature here in order to clarify the stories told and tease out the different meanings of the concept of a "case". I also draw on recent research to show how the stories of litigation have changed over time. Readers who are impatiently wondering what my answer will be (what is a case?) are hereby forewarned: I don't have one answer. Indeed, that is the point of this article, namely, to demonstrate the multiple definitions of a "case" and to encourage scholars to be explicit about the perspective they are taking when arguing about too much or too little litigation. That is, what definition of a "case" are they using? By exploring broad concepts and different theoretical perspectives on litigation, I hope to provide useful background for discussion of some of the data-filled papers presented at this workshop.

At its most basic level, a case is an official legal description of a problem or claim filed in a court. Or, as a quick Google search reveals, a case is "a dispute between opposing parties which may be resolved by a court, or by some equivalent legal process" (Legal case, 2021). Note that a key element of the definition focuses on the filing of the dispute in court or in some other legal venue, without regard to the method of disposition. In other words, we are not concerned with whether a dispute is resolved by adjudication or an alternative, but only with the dispute's entry into a legal forum.

The first part of this article considers the concept of a case from the perspective of the litigant, the party who initiates a dispute in court. In this "bottom-up" perspective, I discuss five different social science approaches, each with its own assumptions about when and why disputing parties go to court. Making these assumptions explicit, as Krislov (1983) suggested in his critique of case load research, can strengthen our understanding of comparative studies of litigation. The second part takes a "top-down" view to look at disputes from the vantage point of government and the legal institutions that create and process cases. From this perspective, state actors extend law, create legal rights, and construct courts to encourage (or discourage) cases from entering them.

The discussion of bottom-up and top-down perspectives focuses only on civil cases due to limits of space in this article. Nevertheless, similar considerations also apply to criminal cases. Indeed, scholars have long noted the malleability of the concept of a 
"criminal case" as dependent on victims to perceive and report crime, on the discretion of police and prosecutors to label and act on it, and on legislative action to designate behavior as "criminal."

\section{Bottom-up (or litigant-focused) perspectives}

\subsection{Social structure and litigation}

Classic social theorists such as Sir Henry Maine, Emile Durkheim, and Max Weber posited a relation between the nature of society and the development and use of a formal legal system. According to the legal development model, as societies become more complex and the division of labor increases, there is greater use of formal law and an increase in civil litigation (Sarat and Grossman 1975, Friedman 1983). In this view, court cases reflect underlying social and economic conditions, with litigation increasing as societies industrialize and develop in complexity. When first tested empirically with 70 years of longitudinal court data from Spain, however, the theory was challenged. Jose Toharia (1974) found that after an initial increase in litigation that paralleled economic growth, litigation then actually decreased. Toharia explained this curvilinear relationship between growth and litigation as due to the introduction of other third-party mechanisms for handling disputes. In more general terms, Black (1976) observed that the parallel relationship between division of labor in a society and its use of law "held up only to a point," after which "legal activity again declined" (Peel 2017, p. 293). Spurred by interest in testing the curvilinear relationship between modernization and civil litigation and in developing a broad paradigm to explain social change and legal development, scholars collected and analyzed docket data over time in different jurisdictions (e.g., Friedman and Percival 1976, McIntosh 1981, Munger 1988, Daniels 1990, Wollschläger 1990, van Loon and Langerwerf 1990). Yet no distinctive developmental paradigm emerged. Instead, these studies found other factors besides modernization to explain civil litigation over time.

Anthropologists of law also investigated the relation between social structure and litigation through ethnographies of dispute settlement (e.g., Gluckman 1955/1967, Gulliver 1963, Bohannan 1965, Nader 1969). They suggested that the multiplex, face-toface relations in villages encouraged compromise through informal dispute processing. In contrast, urban industrial societies were said to use formal legal processes to resolve conflicts because of their lack of societal consensus and impersonal social relations. Although based on comparative research, this literature also implied an evolutionary view. Put simply, in modern societies, "complexity plus estrangement lead to litigation" (Krislov 1983, p. 162).

This vibrant research program of the 1970s and 80s on the relation between social structure and litigation soon disappeared, however. In a recent overview of research on trial courts across time and space, Peel (2017) documents how few studies were published on this topic after the 1990 Special Issue of the Law \& Society Review. ${ }^{2}$ Peel suggests both methodological and normative reasons for the disappearance of this

\footnotetext{
1 See, e.g., Becker 1963, Cicourel 1968 and Skogan 1984 on labeling and reporting crime; La Fave 1965, Wilson 1968 and Frohman 1997 on discretionary arrest and prosecution.

2 See Munger 1990, with articles presented earlier at a Baldy Center conference in Buffalo, NY.
} 
research program. Problems of validity in measuring key units of analysis such as a "case" and "court" plagued the work, as did inferences drawn from imprecise evidence. Second, the modernization paradigm underlying the research "rested on ethnocentric assumptions and failed to appreciate conflicts over inequalities of power" (Peel 2017, p. 295). In a critical review of this research at the time, Kidder (1975, p. 387) emphasized the "misconception, a too-prevalent legacy of Weberian and Durkheimian analysis, that modernization (or the increase of complexity) necessarily and uniformly obliterates older (or simpler) social forms." Similarly, a critique of the developmental paradigm in anthropology pointed to discrepancies between the ideology of dispute processing and the actual practices described in the ethnographic studies, the idealization of face-to-face societies as harmonious and egalitarian, and the inaccurate characterizations of modern courts, which overlooked instances of compromise and mediation (Yngvesson and Mather 1983).

Longitudinal and comparative studies of the use of courts sought to offer a macro-level understanding of the relation between social structure and law. The continuing relations hypothesis provided a micro version of this view: parties with ongoing ties and longterm relationships were said to be less likely to use law to resolve their conflicts than those with episodic ties. Macaulay's (1963) classic study of contract disputes showed that businesses involved in ongoing transactions rarely sued each another, preferring instead to negotiate conflicts in order to preserve their continuing relationships. Other studies noted the relative infrequency of litigation among neighbors or family members (other than divorce where law required it) and among those in small towns with cross-cutting ties (Engel 1984). Black's (1976) theory of law pointed to the importance of relational distance, or intimacy, between parties to explain the use of law for dispute settlement. That is, when social relationships break down or are nonexistent, parties are more inclined to take their problems or claims to court. ${ }^{3}$

What does this research on litigation and social structure imply about the concept of a court case? The macro-level view sees litigation resulting from increased social complexity, more economic transactions, and division of labor (conflict resolution among strangers), while the micro-view sees it as an attempt by those without ongoing ties to assert their interests in the only forum available to them. In a sense, both views reflect "societal 'temperatures.' What is sought is not really litigation but underlying activity and social tendencies" (Krislov 1983, p. 181). This approach suggests, despite the gross oversimplification, a definition of a case something like this:

A case filed in court is a reflection of the amount and nature of social or economic conflict in society, especially between those without close or continuing ties.

\subsection{Rational calculations to litigate}

Economics offers a quite different way to understand litigation, one based on utilitarian calculation of whether the cost of going to court exceeds the expected benefit. The cost is "the time, effort, and legal fees required to complain" while the benefit "depends upon the possible outcomes of settlement bargaining and, in the event bargaining fails, of a

\footnotetext{
${ }^{3}$ See, however, Yngvesson 1985 for reinterpretation of the continuing relations hypothesis, noting important exceptions and qualifications.
} 
trial" (Cooter and Rubinfeld 1990, p. 536). Consistent with this view, as Friedman (1990, pp. 236-7) writes, "the business people in Macaulay's [contracts] study were in many regards ordinary maximizers. [They] had simply learned that nothing was maximized but trouble if they behaved crudely and legalistically, offended their colleagues, and ruined all their comfortable - and profitable - relationships". Hence, businesses avoided contract litigation in order to preserve their relationships, a conclusion supporting both utilitarian and social structure approaches.

Knowing the costs of court in terms of time, resources, and risk, some parties might threaten to go to court simply as a strategic move to encourage or force a negotiated settlement, particularly if one party was less able to undertake the risk of a loss in court. Galanter's (1974) analysis showed that disputing parties are not equally situated with respect to the legal system: "repeat players" (those who regularly use law and courts) are advantaged over occasional users, "one-shotters". For example, repeat players can better anticipate the risks and benefits of litigation. They can play the odds, maximizing gains over a series of cases, even if it entails loss in a few cases. Repeat players also recognize the effect of litigation on legal rules. Consequently, they may settle some disputes with tangible losses in order to benefit from a case establishing favorable rules over the long run. Knowing how to use the court system to stall, repeat players who expect to lose can also delay proceedings to outlast an opposing party and avoid responsibility entirely. In other words, the concept of "gains" or "benefits" of litigation includes not only immediate monetary rewards, but also a broader array of advantages over the long run.

This perspective on litigation emphasizes rational decision making assessing the costs and benefits of using formal legal processes. Economists Cooter and Rubinfeld (1990, p. 534) conceptualize a "legal dispute" as having several distinct stages: "In the beginning there is an underlying event, such as an accident or crime, in which one person (the injurer) allegedly harms another (the victim). In the second stage, the victim or the state asserts a legal claim against the injurer. A dispute arises when there is disagreement over the claim." A court case may emerge in the third stage, as parties attempt to resolve their dispute through bargaining. Estimates of the likely costs in legal fees, time, etc. and the likelihood of expected gains shape parties' decision making about going to court. "Efficient" dispute resolution occurs when legal entitlements are allocated "to those who value them the most" and "transaction costs of dispute resolution are minimized" (Cooter and Rubinfeld, p. 537).

From this perspective of utilitarian calculation of costs and benefits, the definition of a court case might be something like this:

A case filed in court is rational move by an injured party to take formal legal action based on the likelihood of winning and the expectation that the gains from court intervention will outweigh the costs.

\subsection{Dispute transformation}

Instead of conceptualizing disputes as concrete entities or events that move sequentially through distinct stages, dispute transformation focuses on the social construction of cases. Disputes change in form or content through the involvement of other participants and through legal language. A dispute "is not a static event that simply 'happens' but 
instead its structure takes shape over time" (Mather and Yngvesson 1981, p. 776). As friends, family, support groups, lawyers, or others get involved, they add their views in an effort to resolve disputes or to transform them into court cases. Thus, "what a dispute is about, whether it is even a dispute or not, and whether it is properly a 'legal' dispute, may be central issues for negotiation in the disputing process" (Mather and Yngvesson 1981, pp. 776-777).

The focus on the dispute or "trouble case" as a unit of analysis stemmed in part from anthropological research comparing law in different societies (Nader and Todd 1978). Understanding how parties and their supporters respond to injuries or problems involves consideration of the type of injury or problem, its location, and the people involved. One approach to dispute transformation, similar to the economic model discussed above, sees disputing as a series of different stages but, unlike the economic model, sees contingency and change in the dispute itself. A dispute is "fundamentally a social relationship" that takes on different characteristics over time (Kritzer 2011, p. 14). As Felstiner and coauthors (1981) suggested, in order for a dispute to emerge, an injury must first be perceived as such ("named"), then the alleged injurer "blamed", and finally a remedy sought by the injured party asserting a "claim." Their approach is associated with the metaphor of a "disputing pyramid." Using survey data of people's experiences with potential legal problems, Miller and Sarat (1981) created a pyramid with a wide base of grievances at the bottom, fewer reports of blame, and even fewer of legal claims, and at the top, very few court cases. Studies of disputing pyramids in other countries found parallels to the U.S. pattern in that difference in problem type (e.g., accident, family, discrimination) accounted for much of the difference in the shape of the pyramids (Genn 1999, Kritzer 2011, Murayama 2012).

A dialectic perspective on dispute transformation emphasizes the different ways in which disputes are narrowed and expanded through negotiations during the disputing process (Santos 1977, Mather and Yngvesson 1981, 2015). Narrowing imposes established categories on an event, routinizing its handling to reflect the interests and language of third-party institutions. Arguments between parties and their supporters often center on reasons to choose one narrowing framework over another, anticipating how the framework can greatly influence the outcome of a dispute. Disputes are expanded through a process of asserting new ways of framing them, using normative categories not previously accepted by third parties and often appealing to a broader audience. Expansion thus encourages people "to change the perspective through which disputes are commonly perceived" and offers the possibility of altering the political order by providing legal language to change local practices (Mather and Yngvesson 1981, p. 779). Dispute transformation through the dialectic of narrowing and expansion also shows how individual actions can maintain and/or modify social structure.

Focus on the social, political, and linguistic construction of disputes by the parties and other participants involved suggests a third way to think about the concept of a case:

A case filed in court is the legal framework given to a perceived injury or problem at a particular point in time, resulting from negotiations between disputing parties, their supporters, a third party, and others. 


\subsection{Legal mobilization as political participation}

The concept of narrowing suggests how the language and processes of disputing work to maintain law. Using legal language to frame individual problems gives specific content to the abstract legal words and categories. By invoking law, private citizens and groups thus play a critical role in its enforcement; legal mobilization should be seen as a form of political participation just as lobbying or voting (Zemans 1983). Litigation may also play a role in changing law through dispute expansion. By asserting new ways of thinking about problems, offering new language to frame them, mobilizing support, and attracting an audience, individuals and groups sometimes challenge existing law and provide opportunities for legal change.

Echoing this early literature on legal mobilization and the political order, Lahav's (2017) recent book, In Praise of Litigation, describes two other virtues of litigation (in addition to law enforcement and political participation): promotion of transparency and furtherance of a form of social equality. Transparency means that when parties file suits in court, they can open up discussion about important issues: litigation "provides a public forum in which discussions of competing values - in the particular factual context giving rise to the conflict - may proceed with input from all interested parties" (Lahav 2017, p. 3). Not all societies allow such discussions and their broader impact is affected by the degree to which dispute processing arenas are open or closed to the public (Yngvesson and Mather 1983). Open courts can provide the opportunity for public discussion of conflicting values that Lahav praises. Finally, litigation can promote social equality by allowing disputing parties equal opportunities to speak and be heard. Although lack of resources or inexperience with legal process can disadvantage the weaker party, litigation nevertheless can provide an official hearing for a disputant's claim and a public occasion to assert one's legal rights - with at least a formal expectation that all claimants are equal before the law.

Taking advantage of the transparency and formal equality of litigation, interest groups have a long history of using courts to try and change law. Known as "test case litigation" in the United States or as "strategic litigation" in the global arena, these lawsuits use individual or group claims in an effort to obtain a favorable judicial ruling and set new legal precedent. Even if initially unsuccessful in court, the litigation can raise awareness of an issue, legitimize the claim, attract publicity and provoke discussion, and may eventually lead to legal change. Well-known examples of test case litigation in the United States include litigation over racial segregation in housing and schools (Vose 1959, Kluger 1975), prison conditions (Feeley and Rubin 1998), school financing (Reed 2001), responsibility for tobacco harms (Mather 1998), and gay marriage (Levy 2013). Conservative interest groups have also used test case litigation to expand the constitutional rights of property holders (Hatcher 2005) and gun owners, and to oppose abortion (Horan et al. 1987) and affirmative action. Beyond domestic politics, interest groups have taken advantage of global legal agreements and the establishment of regional and international legal tribunals to use litigation in politically targeted ways. Amnesty International, for example, touts its engagement in strategic litigation since 1987 and its successful record in obtaining landmark rulings on human rights across a range of jurisdictions (https://www.amnesty.org/en/strategic-litigation/). A strategic campaign of litigation before the European Court of Justice expanded gender equality 
and workplace law in Great Britain, achieving what Alter and Vargas describe as "an important shift in the domestic balance of power" (Alter and Vargas 2000, p. 465). As observers have noted, however, litigation has no guarantee of success and requires extrajudicial resources and continued political struggle to enforce judicial decisions and avoid backlash (Rosenberg 1991, Alter and Vargas 2000, Haltom and McCann 2004).

A political perspective on litigation emphasizes the political and legal ramifications of the assertion of individual claims. It acknowledges occasions of conscious intention by parties to enforce their legal rights or use their problems to communicate the need for legal change. Hence, we might say that:

A case filed in court is a strategic vehicle designed to raise awareness of a problem by compelling government action to enforce law or by obtaining clarification or statement of new law.

\subsection{Psychological perspectives on litigation}

Psychologists have looked to personality differences to identify those who engage in litigation. In this view, "litigious" individuals are quick to take offense, more likely to blame others for their problems, and to seek redress through external channels such as law. Katvan and Shnoor's (2021) article illustrates this point well. They report on the personality attributes of "serial litigants" in Israel, a small group of individuals who file numerous legal claims and go to court for every problem and complaint they have, no matter how minor. At the other extreme are individuals who passively accept their problems and injuries, that is, who "lump it" in Felstiner's (1974) phrase.

Early scholars such as Coates and Penrod (1981) and Vidmar and Schuller (1987) explored the role of individual differences in claiming behavior. The latter, for example, developed a measure of "claim propensity" that included six components: "aggressiveness, competitiveness, assertiveness, perceptions of control, preference for risk, and preference for winning over compromise" (Kritzer 2011, p. 16). Claim propensity was significantly associated with the likelihood by individuals to seek to resolve their problems by filing claims in court. More recently, Blackstone and coauthors (2009) studied individual responses to sexual harassment, which included a measure of "self-efficacy" in their quantitative analysis. However, this was not found to be significant in explaining responses to harassment. The presence of close work friends, however, was a significant predictor of legal mobilization in the study.

More generally, scholars have recognized the importance of one's social network for individual responses to problems and injuries. Engel (2016) draws on recent cognitive science research to explain why the vast majority of people with injuries do not sue. They lump it. Why? "Injury victims," he writes, "like most humans, are embedded in social networks that influence their thoughts and actions" (Engel 2016, p. 166). And although social influence could act either to encourage or discourage claiming, in practice it tends "most often to encourage lumping" due to cultural norms and negative social stereotypes of aggressive claiming behavior (Engel 2016, p. 167). Moreover, cognitive science has shown the impossibility of separating mind and body. Cognition is "embodied", which means, in Kahneman's words, that "you think with your body, not only with your brain" (quoted in Engel 2016, p. 53). Much of our thinking is automatic, non- 
conscious, and prone to cognitive biases that tend to reinforce the status quo. This could encourage passive, lumping behavior over filing claims for injuries.

Studies of legal consciousness also challenge the notion that individual responses to injuries and problems reflect rational, conscious decisions to seek or avoid a remedy through law. Legal rights are fundamentally connected to individual identities (Engel and Munger 2003). Engel and Munger's in-depth study of individuals who experienced discrimination due to their disabilities revealed how knowledge of legal rights under the Americans for Disabilities Act was only one aspect of how they experienced their treatment by employers, schools, and others. Identities developed over a lifetime also "determine how and when [legal] rights become active," yet, as their recursive theory argues, "rights can also shape identity" (Engel and Munger 2003, p. 242). Rights generate ideas of right and wrong, of responsibility, and of the role of law in everyday life. The important constitutive role of law has also been shown in how people understand and describe their problems in local courts (Yngvesson 1993), in the different cultural schema for using and experiencing law (Merry 1990, Ewick and Silbey 1998) and in the collective action frameworks for responding to sexual harassment (Marshall 2003).

Emphasis on individual perceptions of problems and injuries and on the available cultural frameworks for response reveals the extent to which the filing of a legal claim involves much non-conscious activity and does not proceed in a linear, rational way. We might say then,

A case filed in court is the product of unconscious influences including the embodied mind, individual identity, social networks, and cultural frames.

\subsection{Summary}

As is clear from this short review of the literature, the concept of a case filed in court rests on strikingly different assumptions about claiming behavior by scholars in different fields. Classical economists and some political scientists view litigation as the result of individual agents making rational decisions. For the former, filing a claim reflects a calculated assessment of likely gains outweighing legal costs, while for the latter, a claim is a strategic vehicle for enforcing law or seeking to change law. By contrast, for anthropologists and sociologists, individual agency is not separable from social context and relations with others. Individuals' claims reflect the history and relational context of disputes, the language and resources available, and their cultural setting. A case filed in court reflects a social and linguistic construction of a dispute through narrowing or expansion to incorporate values and interests besides those of the claimant. Although psychologists have initially focused on personality differences to explain case filings, more recent work in cognitive science emphasizes the unconscious, embodied nature of thinking and the cognitive biases that shape claiming behavior. Research on cognition has also shaped the new field of behavioral economics, underscoring limits on rationality and calling attention to framing effects, use of heuristics, mental shortcuts and cognitive biases. Thus, what it means to file a case in court not only differs by field, but such meanings have also changed over time with new research about human behavior. Instead of viewing individual claimants as fully autonomous, rational decision makers intentionally preferring court over alternatives, researchers should adopt frameworks 
that consider claimants as embedded in social and political contexts, shaped by cultural assumptions, with embodied thinking.

Before proceeding to the next section, I must acknowledge two important gaps in the literature discussed here. First, the party filing a case is generally conceived of as an individual, leading to generalizations about individual behavior. Yet businesses, groups, and other organizations frequently initiate litigation, perhaps even more often than individuals. But claiming behavior by organizations has received far less attention in research. Second, what about lawyers? A more complete picture of the bottom-up perspective would include the role lawyers play in counseling clients about filing claims, in shaping their views of law and court processes, in discouraging litigation by high legal fees, in encouraging litigation to advance a cause, and so forth. Since considerable research has addressed the role of lawyers in litigation, it has been omitted here (see, e.g., Cain 1979, Mather 1998, 2018, Sarat and Scheingold 1998, Kagan 2001, Kritzer 2004, Levin and Alkoby 2021).

\section{Top-down (or government-focused) perspectives}

What can we say about litigation from the perspective of government? Ruling political regimes establish and maintain courts due to their essential value for conflict resolution and social control (Shapiro 1980). Governments construct courts strategically for both these functions in ways that directly affect the cases filed in them. Additionally, institutional features of courts influence the number and types of cases filed.

\subsection{Courts and conflict resolution}

In a classic analysis of courts, Shapiro (1980) describes the root concept of the triad: when two parties cannot solve a conflict themselves, they often turn to a third party for assistance. The social invention of the triad, he argues, is "universal across both time and space ... and from its overwhelming appeal to common sense stems the basic political legitimacy of courts everywhere" (Shapiro 1980, p. 1). Yet despite its appeal, the triad has an inherent instability. As soon as the third party decides in favor of one of the disputants, the structure changes. The losing disputant then perceives a two against one situation in which the loser is outnumbered.

To avoid the instability of the triad and maintain the political legitimacy of courts, Shapiro writes, societies use two devices: consent and the mediating continuum. Both disputants consent in advance to accept the rules and decision of the third-party. And third parties avoid imposing dichotomous decisions that would create a two against one scenario (Shapiro 1980, pp. 2-4). How do these devices work in practice for governments seeking stability for their courts? For consent, it helps to have rules and third parties perceived to be impartial in order to reassure disputants in advance. The mediating continuum can be approximated by offering alternatives to adjudication, such as mediation or arbitration, and by judicial decisions that involve some degree of compromise.

Since political regimes always prefer some interests over others, a challenge lies in conveying courts' lack of bias in order to persuade disputants to bring their disputes there. Procedural restrictions on litigation that on their face appear completely neutral provide one way. They also serve the interests of the regime by limiting what kinds of 
disputes can enter courts. Consider restrictions such as justiciability, standing, and jurisdiction. Justiciability narrows eligibility of conflicts to "live" cases or controversies. In early challenges to state abortion law, U.S. courts used this doctrine to reject womens' claims, since by the time the issue was before a judge, the pregnancy was over. ${ }^{4}$ And when a white student challenged the constitutionality of affirmative action, the Supreme Court ruled there was no live issue because the student had nearly graduated by the time of the Court's decision (DeFunis v. Odegaard, 1974). Courts also require standing, meaning that a challenger must be able to show real and direct harm. Some environmental legal claims have been blocked from court due to this restriction since the procedural question becomes who exactly has suffered the harm? Or, as Dr. Seuss wrote in his children's book, The Lorax, "who speaks for the trees?" Jurisdiction requires that a court be the properly designated one to hear a claim. Thus, federal courts in the U.S. are unable to hear many state legal claims due to lack of a federal issue.

While procedural requirements such as these appear as fixed, judges have discretion to modify them if they want to hear a case. The political question doctrine illustrates this point well. The doctrine asserts that only legal questions are justiciable, not political ones, yet the boundary between law and politics is set by judges themselves. Legal rules about group claims also illustrate this point. A change in the Federal Rules of Civil Procedure, along with similar changes in state rules and political pressure from consumer, civil rights and environmental groups, led to an increase in class action litigation in the U.S. after the 1960s. Other countries, such as Canada, much of Europe, and some in Latin America also changed court rules to allow class action lawsuits. But in the past decade, the U.S. Supreme Court has made it harder to file class action claims. ${ }^{5}$ In short, dominant political regimes can change the rules of the litigation game according to which disputants - and how many - they want to attract or discourage.

Governments also create alternatives to courts for conflict resolution such as pre-trial settlement, mediation, and arbitration. These alternative forms of dispute resolution ("ADR") support the legitimacy of the triad by incorporating the mediating continuum into government arenas for handling disputes. ADR advocates have extolled its virtues, including producing settlements more attuned to individual features of a case and arguably greater success for compliance with agreements (Menkel-Meadow 1984). Yet ADR critics complain that it creates a two-tier system in which the wealthier, more organized parties use courts, while less powerful, individual claimants - divorce, labor, consumers - are directed to ADR (Harrington 1985). The expansion of ADR for individual disputes provides another illustration of how government can influence the number and type of lawsuits filed in its courts.

From the perspective of the state and its interest in maintaining the legitimacy of courts for resolving conflicts, we might say that:

A case filed in court is a conflict shaped specifically to meet the requirements of the state, and deemed eligible by the state for court intervention, rather than handling by ADR.

\footnotetext{
${ }^{4}$ In Roe $v$ Wade, 1973, the Supreme Court overturned this position, ruling that pregnancy was an issue "capable of repetition, yet evading review".

5 See, e.g., Wal-Mart v Dukes, 2011, and Bristol-Meyer Squibb Co. v. Superior Court of California, 2017.
} 


\subsection{Courts, social control and lawmaking}

When courts engage in conflict resolution, they do more than just handle individual disputes. By processing disputes through legal frameworks, courts simultaneously engage in social control and occasionally lawmaking. That these three functions "must be seen as mutually interdependent" (Shapiro 1980, p. 17) is illustrated by two wellknown ethnographic studies of local courts. Yngvesson (1993) describes how clerks in local Massachusetts courts respond to people's everyday complaints by separating "garbage cases" from those that the clerk believes deserve legal attention. She notes that even as one clerk "weeded out" petty complaints, he also listened, thus connecting legal space and local space. "This transformed the courthouse into an institution that could share the surveillance of 'the other half of America' with the social workers whose clients appeared there so regularly (...) but it also created space for hearing the 'little problems' of people (...) whose demands for a livable neighborhood were sometimes heard by the court clerk" (Yngvesson 1993, p. 121). Similarly, Merry (1990) notes the "paradox of legal entitlement" in her study of a working-class local court: "as these working-class court users seek to assert their sense of entitlement to legal relief $(. .$.$) they find that it is denied$ by the courts. The court does not reject their requests out of hand but subjects them to periods of monitoring, to probationary supervision, to social services" (Merry 1990, p. 180). Thus, even as plaintiffs become empowered by the law in their neighborhood disputes, they lose that power as they become dependent on the state, in the form of the courts. In both of these studies, courts extend control over communities in the process of hearing disputes of local residents. ${ }^{6}$

Social control through courts also rests on the content of law. Law communicates normative order backed by the power of the state. Law expresses fundamental values, differentiates between right and wrong conduct, and provides sanctions for violations. Using words and concepts that become well-known over time and engrained in communities (even if not always accepted or followed), the state narrows problems into legal language to facilitate their handling by courts. When new problems arise, which the state decides to name as legal violations, aggrieved parties can file claims in court for redress. In this sense, it is the new statutes themselves that create and increase litigation. During the 1960s and 1970s, the U.S. Congress responded to civil rights, labor, and environmental problems with legislation such as the Equal Pay Act, Civil Rights Act, Occupational Health and Safety Act, Environmental Protection Act, Clean Air Act, Clean Water Act, and others. Individuals and groups then filed lawsuits to take advantage of these laws, that is, to frame their complaints against employers, educational institutions, and industries as lawsuits to enforce the new laws. The President also issues new law through executive orders, sometimes to avoid Congressional stalemates or opposition. In recent years, executive orders by Presidents Obama and Trump have influenced the number of lawsuits by expanding or weakening existing federal law.

Courts also engage in lawmaking when they clarify the ambiguities of vague statutes. The fact that judicial decisions can also change the meaning of statutes leads to an increase or decrease in the cases claiming those legal rights. For example, when Lilly Ledbetter sued Goodyear Tire \& Rubber Co. under Title VII of the Civil Rights Act to

\footnotetext{
${ }^{6}$ Although these two studies focus more on minor criminal cases than civil disputes, I include them because they illustrate the point so well.
} 
recover decades of back wages due to pay discrimination, the Supreme Court denied her claim. The Court narrowed the scope of the statute to cover only discrimination that occurred within 180 days or less, even though Ledbetter was unaware of the pay discrepancy until she retired (Lilly Ledbetter v Goodyear, 2007). This 5-4 decision in 2007 sent a clear message to discourage future lawsuits such as hers. The result, however, was political mobilization against the decision and passage of legislation in 2009 that effectively overruled the Court on this point. ${ }^{7}$

In addition to filling in the blanks of statutes, courts influence litigation by signaling their willingness to entertain new legal arguments or, conversely, to shut them down. Such normative messages from courts encourage or discourage legal claims. For example, after courts found asbestos manufacturers liable for the harms caused by their products, there was an increase in claims against tobacco manufacturers for the harms of cigarette smoking (Galanter 1990, Mather 1998). Galanter analyzes groups of cases like these case congregations - and points to their shared features and common histories. While external forces drive some of these case congregations, the cases are also a product of the legal system itself, living a life of their own. Galanter concludes, "when we see changes in litigation over time, we see reflections of changes in the resources, alternatives, and strategies available to the players" (Galanter 1990, p. 394). In an earlier article, Galanter describes some of these resources, alternatives and strategies as important "bargaining endowments" and "regulatory endowments" conveyed by judicial decisions (Galanter 1983, p. 121).

Courts exercise social control especially in countries like the United States that rely on what Kagan (2001) calls "adversarial legalism" as their system of governance. Instead of top-down, problem solving by experts or bureaucrats, adversarial legalism provides a method of policy implementation and dispute resolution that depends on parties to initiate claims using formal, legalistic rules and procedures. That is to say, it encourages litigation. Moreover, the centrality of law and courts in the United States, Kagan argues, stems not from Americans' cultural inclinations to sue, but from the country's structural incentives for litigation and a lack of institutional alternatives (Kagan 2001, p. 34). Where other countries have developed a wide array of informal alternatives for dispute resolution without law, the United States has not, instead relying heavily on lawyers and judges.

Reliance on courts and judicial authority to resolve policy conflicts has greatly increased around the globe (Shapiro 1993). Indeed, the judicialization of politics is "arguably one of the most significant phenomena of the late twentieth and early twenty-first century government" (Hirschl 2008, p. 119). This trend has been fueled by increased attention to constitutional rights and the role of high courts in interpreting them, greater willingness by judges to address public policy debates, a vibrant network of lawyer advocacy groups mobilizing legal rights, and political support for - or at least, acquiescence in - judicial power in politics by political regimes. Even authoritarian regimes recognize the crucial political functions that courts can provide. Courts can aid the regime in exercising social

\footnotetext{
7 The Lilly Ledbetter Fair Pay Act was the first bill Obama signed when he became President in January 2009.
} 
control, provide it with some legitimacy, and handle controversial issues in order to insulate the regime from political backlash (Moustafa and Ginsburg 2008).

In light of how courts exercise social control and engage in lawmaking, we can see the importance of courts for political regimes. We could even say,

A case filed in court is a vehicle for the state to expand control over people's affairs and differentiate rights and wrongs to be backed by the power of the state. A case reflects incentives provided by the state to encourage resolution of certain kinds of disputes in court, rather than elsewhere.

\subsection{Institutional capacity of courts}

Besides the political motives for states to influence litigation, there are also resource constraints that lead them to try and match the number of cases with the capacity of courts to handle them. Of course, resource arguments often reflect underlying political concerns, but it is worth considering the concept of a case from the standpoint of efficiency. Small claims courts, for example, exist in many countries to provide quicker, less expensive arenas for resolution of civil cases involving small amounts of money. When civil courts become overcrowded, administrators lobby to change the jurisdiction of small claims courts by increasing the limit for claims filed there, thus moving some civil cases out of regular courts. Similarly, one of the purposes of ADR is to bring a degree of political economy to dispute resolution by structuring a "multi-door courthouse" that channels cases to the most appropriate forum for resolution, thus saving "time and money for both the courts and the participants or litigants." 8

The establishment of specialized courts to handle similar kinds of cases provides another example of government seeking judicial efficiency (Baum 2011). In the United States, specialized federal courts include tax, claims, bankruptcy, patent and trademark, and international trade. Some states have specialized civil courts for family law or probate, and many have specialized drug courts. Civil law countries in Western Europe tend to have more specialized courts than common law countries, in part due to parallels between the judiciary and the bureaucracy (Baum). When specialist judges handle only cases in a certain field, they develop factual and legal expertise that promotes more efficient handling over what a generalist judge could do. Baum notes another gain in expected efficiency as well: "generalist courts can work through their caseloads more quickly if they are no longer responsible for the cases that go to a specialized court or if they never receive those cases in the first place" (Baum 2011, p. 33). Besides efficiency, of course, specialized courts also enhance the possible influence of special interest groups and possibly increase bias in judges as they gain experience in a particular field.

Governments also pass laws aimed at lawyers as a way to influence litigation. For instance, Japan's historic limits on the number of new lawyers allowed admission each year partially explains the low litigation rate in that country (Murayama 2012). Lawyers' fee structures also encourage or discourage their willingness to represent certain kinds of claims. Comparison of the contrasting trajectories of the anti-tobacco litigation in the

8 PON staff 2019. Program on Negotiation, Harvard Law School. Harvard Law Professor Frank E.A. Sander introduced the concept of the multi-door-courthouse in 1976 and the Program on Negotiation has continued to promote the idea. 
U.S. and Britain underscores this point (Mather 2009). The contingency fee in the U.S. incentivized plaintiff lawyers to pursue cases against tobacco manufacturers, while their counterparts in Britain faced a "loser pays" rule, which shifts costs to unsuccessful plaintiffs from defendants who win. Although Britain and Australia have traditionally had government-funded legal aid for civil litigants, increased program costs led to caps and a reduction of legal services in order to save money (Granfield and Mather 2009). Advocates of government funding for civil legal aid in the U.S. have faced even greater obstacles, with opposition based both on cost and politics.

Government interest in the cost of litigation may focus less on the costs to litigants and more on the total cost of administering courts. Courts are bureaucratic institutions that require physical buildings with equipment and security, as well as judicial salaries and adequate staff. Consequently, concerns about institutional capacity may affect government decisions about the number and types of cases that can enter different courts or be directed elsewhere. From this perspective, we might say,

A case filed in court is a demand for state resources. Court administrators seek an equilibrium between the number of cases and the resources needed to process them.

\subsection{Summary}

Just as we saw different meanings for the concept of a case from the perspective of the individual filing a claim, the discussion in this section has shown how cases represent many different things from the perspective of government. Cases can provide political legitimacy to regimes by having courts resolve conflict in society. Cases also aid government in social control by extending the reach of government into private transactions or by enforcing law against actions labelled illegal. Governments occasionally use cases as vehicles for lawmaking by courts. A case can be a request for judicial resolution of a controversial issue so that the executive and legislature can avoid political responsibility for a decision. And cases present a demand for state resources since courts require staff and financing to operate. Note that asking why we care about the number of cases in litigation provides different answers according to what we think is important about those cases. That is to say, when we count cases in litigation, we are using numbers to decide what matters (Stone 2020).

\section{Conclusion}

Review of these quite different concepts of what a case is underscores the need to be explicit about why one is asking the question, is there too much litigation? If one's concern is how to structure courts so as to maximize their efficiency in processing disputes, then attention should be paid to litigants' utilitarian considerations, costs of case processing, and the institutional capacity of courts. But concern about inequality of court outcomes (why the haves come out ahead) points to different issues - e.g., access to justice and litigants' knowledge and experience with courts. A third concern about litigation centers the role of courts in governance and social control. To the extent that cases serve as vehicles for allocating values and making law, then one might ask about independence of judges and the transparency of court processes.

Research on litigation should integrate bottom-up and top-down perspectives. Studies that ignore either the litigants who file cases or the concerns of the state in handling 
litigation will miss important parts of the story. Consider how these two perspectives influence and shape one another. For example, to the extent that an increase in litigation reflects increased social or economic conflict in society, the resulting disorder and malaise could threaten regime stability. One government response might be to increase court capacity to handle more cases. Alternatively, a government might develop alternatives to courts to provide what it believes to be more effective ways to handle disputes, thus narrowing the category of cases eligible for court. An entirely different approach could involve lawmaking, extending regulation or creating new law to address what the government sees as systemic problems underlying the individual disputes. A focus only on the motivations of claimants would miss the ways in which their options have been shaped by the regime for its own political interests.

Similarly, when courts resolve individual conflicts, they also communicate to a wider audience, advantaging some interests over others. To the extent that judges endorse new legal arguments or convey support for different disputants than in the past, they encourage others to file claims to assess the boundaries of law. Litigants and supporting interest groups may use these opportunities to file strategically designed test cases (e.g., civil rights or anti-abortion) or to file masses of claims (e.g., asbestos or anti-tobacco). In other words, the political motives of litigants to file suits might coincide with government interests in lawmaking, reinforcing one another. Or they might act in opposition, as when litigants file cases to overturn government lawmaking believed to be inconsistent with legal standards.

In sum, longitudinal research on litigation should attend not only to change in the number of claims filed over time, but also to changes in substantive and procedural law, in the boundaries of courts, and in court alternatives. Similarly, comparative work needs to look at differences in the identities of claimants, their social contexts, problem types, costs of legal claims and availability of legal services, as well as differences in the role of courts in governance and their institutional capacities. By recognizing the diverse meanings of a "case", we will understand more clearly the different stories being told by the number of claims filed in court.

\section{References}

Alter, K., and Vargas, J., 2000. Explaining variation in the use of European litigation strategies: European Community law and British gender equality policy. Comparative Political Studies [online], 33(4), 452-482. Available from: https://doi.org/10.1177/0010414000033004002 [Accessed 1 March 2021].

Baum, L., 2011. Specializing the Courts. University of Chicago Press.

Becker, H., 1963. Outsiders: Studies in the Sociology of Deviance. Chicago University Press. Black, D., 1976. The Behavior of Law. New York: Academic Press.

Blackstone, A., Uggen, C., and McLaughlin, H., 2009. Legal consciousness and responses to sexual harassment. Law and Society Review [online], 43(3), 631-666. Available from: https://doi.org/10.1111/j.1540-5893.2009.00384.x [Accessed 1 March 2021]. 
Bohannan, P., 1965. The differing realms of law. American Anthropologist [online], 67(6), 33-42. Available from: https://doi.org/10.1525/aa.1965.67.6.02a00930 [Accessed 1 March 2021].

Cain, M., 1979. The general practice lawyer and the client: towards a radical conception. International Journal of the Sociology of Law, 7, 331.

Cicourel, A., 1968. The Social Organization of Juvenile Justice. New York: Wiley.

Coates, D., and Penrod, S., 1981. Social psychology and the emergence of disputes. Law and Society Review [online], 15(3-4), 655-680. Available from: https://doi.org/10.2307/3053506 [Accessed 1 March 2021].

Cooter, R.D., and Rubinfeld, D.L., 1990. Trial courts: An economic perspective. Law and Society Review [online], 24(2), 533-546. Available from: https://doi.org/10.2307/3053694 [Accessed 1 March 2021].

Daniels, S., 1990. Caseload dynamics and the nature of change: The civil business of trial courts in four Illinois counties. Law and Society Review [online], 24(2), 299320. Available from: https://doi.org/10.2307/3053680 [Accessed 1 March 2021].

Engel, D.M., 1984. The oven bird's song: Insiders, outsiders, and personal injuries in an American Community. Law and Society Review [online], 18(4), 551-582. Available from: https://doi.org/10.2307/3053447 [Accessed 1 March 2021].

Engel, D.M., 2016. The Myth of the Litigious Society: Why we Don't Sue. Chicago University Press.

Engel, D.M., and Munger, F.W., 2003. Rights of Inclusion: Law and Identity in the Life Stories of Americans with Disabilities. University of Chicago Press.

Ewick, P., and Silbey, S.S., 1998. The Common Place of Law: Stories from Everyday Life. University of Chicago Press.

Feeley, M.M., and Rubin, E., 1998. Judicial Policy Making and the Modern State: How the Courts Reformed America's Prisons. New York: Cambridge University Press.

Felstiner, W.L.F., 1974. Influences of social organization on dispute processing. Law and Society Review [online], 9(1), 63. Available from: https://doi.org/10.2307/3053022 [Accessed 1 March 2021].

Felstiner, W.L.F., Abel, R.L., and Sarat, A., 1981. The emergence and transformation of disputes: Naming, blaming, claiming. Law and Society Review [online], 15(3-4), 631-654. Available from: https://doi.org/10.2307/3053505 [Accessed 1 March 2021].

Friedman, L.M., 1983. Courts over time: A survey of theories and research. In: K.O. Boyum and L. Mather, eds., Empirical Theories About Courts. New York: Longman, 9-50.

Friedman, L.M., 1990. Opening the time capsule: A progress report on studies of courts over time. Law \& Society Review [online], 24(2), 229-240. Available from: https://doi.org/10.2307/3053675 [Accessed 1 March 2021]. 
Friedman, L.M., and Percival, R.V., 1976. A tale of two courts: Litigation in Alameda and San Benito counties. Law and Society Review [online], 10(2), 267. Available from: https://doi.org/10.2307/3053101 [Accessed 1 March 2021].

Frohman, L., 1997. Convictability and discordant locales: reproducing race, class, and gender ideologies in prosecutorial decision-making. Law \& Society Review [online], 31(3), 531-66. Available from: https://doi.org/10.2307/3054045 [Accessed 1 March 2021].

Galanter, M., 1974. Why the "Haves" comes out ahead: Speculations on the limits of legal change. Law and Society Review [online], 9(1), 95-160. Available from: https://doi.org/10.2307/3053023 [Accessed 1 March 2021].

Galanter, M., 1983. The Radiating Effects of Courts. In: K.O. Boyum and L. Mather, eds., Empirical Theories About Courts. New York: Longman, 117-142.

Galanter, M., 1990. Case congregations and their careers. Law and Society Review [online], 24(2), 371-395. Available from: https://doi.org/10.2307/3053686 [Accessed 1 March 2021].

Genn, H., 1999. Paths to Justice. Oxford: Hart.

Gluckman, M., 1967. The Judicial Process among the Barotse of Northern Rhodesia. Manchester University Press. (Originally published in 1955).

Granfield, R., and Mather, L., 2009. Pro bono, the public good, and the legal profession: An introduction. In: R. Granfield and L. Mather, eds., Private Lawyers and the Public Interest: The Evolving Role of Pro Bono in the Legal Profession. Oxford University Press, 1-22.

Gulliver, P.H., 1963. Social Control in an African society: A Study of the Arusha, Agricultural Masai of Northern Tanganyika. Boston University Press.

Haltom, W., and McCann, M., 2004. Distorting the Law: Politics, Media, and the Litigation Crisis. University of Chicago Press.

Harrington, C.B., 1985. Shadow Justice: The Ideology and Institutionalization of Alternatives to Court. Westport: Greenwood Press.

Hatcher, L., 2005. Economic Libertarians, property, and institutions: linking Activism, ideas, and identities among property rights advocates. In: A. Sarat and S. Scheingold, eds., The World Cause Lawyers Make. Redwood City: Stanford University Press, 112-146.

Hirschl, R., 2008. The judicialization of politics. In: K.E. Whittington, R.D. Kelemen and G.A. Caldeira, eds., The Oxford Handbook of Law and Politics. Oxford University Press.

Horan, D.J., Grant, E.R., and Cunningham, P.C., eds., 1987. Abortion and the Constitution: Reversing Roe v Wade through the Courts. Washington, DC: Georgetown University Press.

Kagan, R.A., 2001. Adversarial Legalism: The American way of law. Cambridge, MA: Harvard University Press. 
Katvan, E., and Shnoor, B., 2021. Don Quixote de la Corte: Serial Litigants, Emotions, and Access to Justice. Oñati Socio-Legal Series [online], 11(this issue). Available from: https://doi.org/10.35295/osls.iisl/0000-0000-0000-1117 [Accessed 1 March 2021].

Kidder, R., 1975. Afterword: Change and structure in dispute processing. Law \& Society Review [online], 9(2), 385. Available from: https://doi.org/10.2307/3052983 [Accessed 1 March 2021].

Kluger, R., 1975. Simple Justice. New York: Alfred A. Knopf.

Krislov, S., 1983. Theoretical perspectives on case load studies: A critique and a beginning, In: K.O. Boyum and L. Mather, eds., Empirical Theories About Courts. New York: Longman, 161-187.

Kritzer, H.M., 2004. Risks, Reputations, and Rewards: Contingency Fee Legal Practice in the United States. Redwood City: Stanford University Press.

Kritzer, H.M., 2011, The antecedents of disputes: Complaining and claiming. Oñati Socio-Legal Series [online], 1(6), 1-31. Available from: http://opo.iisj.net/index.php/osls/article/viewFile/53/225 [Accessed 1 March 2021].

LaFave, W., 1965. Arrest: The Decision to Take a Suspect into Custody. Boston: Little, Brown \& Co.

Lahav, A., 2017. In Praise of Litigation. New York: Oxford University Press.

Legal case, 2021. Wikipedia [online], 3 January. Available from: https://en.wikipedia.org/wiki/Legal_case [Accessed 1 March 2021].

Levin, A., and Alkoby, A., 2021. More lawyers, more litigation? Exploring trends in litigation and the legal profession in Ontario, Canada. Oñati Socio-Legal Series [online], 11(this issue). Available from: https://doi.org/10.35295/osls.iisl/00000000-0000-1118 [Accessed 1 March 2021].

Levy, A., 2013. The perfect wife. The New Yorker, 30 September, 54-63.

Macaulay, S., 1963. Non-Contractual relations in business: A preliminary study. American Sociological Review [online], 28(1), 55. Available from: https://doi.org/10.2307/2090458 [Accessed 1 March 2021].

Marshall, A., 2003. Injustice frames, legality, and the everyday construction of sexual harassment. Law and Social Inquiry [online], 28(3), 659-689. Available from: https://doi.org/10.1111/j.1747-4469.2003.tb00211.x [Accessed 1 March 2021].

Mather, L., 1998. Theorizing trial courts: Lawyers, policymaking, and tobacco litigation. Law and Social Inquiry [online], 23(4), 897-940. Available from: https://doi.org/10.1111/j.1747-4469.1998.tb00037.x [Accessed 1 March 2021].

Mather, L., 2009. Lawyers and Solicitors Separated by a Common Legal System: AntiTobacco Litigation in the United States and Britain. In: D.M. Engel and M. McCann, eds., Fault Lines: Tort Law as Cultural Practice. Redwood City: Stanford University Press.

Mather, L., 2018. Client selection: How lawyers reflect and influence community values. In: M.N. Trautner, ed., Insiders, Outsiders, E Law [online]. Cambridge 
University Press, 82-97. Available from:

https://doi.org/10.1017/9781316979716.006 [Accessed 1 March 2021].

Mather, L., and Yngvesson, B., 1981. Language, audience, and the transformation of disputes. Law and Society Review [online], 15(3-4), 775-821. Available from: https://doi.org/10.2307/3053512 [Accessed 1 March 2021].

Mather, L., and Yngvesson, B., 2015. Disputes, social construction and transformation of. In: J.D. Wright, ed., International Encyclopedia of the Social and Behavioral Sciences. $2^{\text {nd }}$ ed. [online]. Elsevier, 560-566. Available from: https://doi.org/10.1016/B978-0-08-097086-8.86024-9 [Accessed 1 March 2021].

McIntosh, W., 1981. 150 Years of litigation and dispute settlement: a court tale. Law and Society Review [online], 15(3-4), 823-848. Available from: https://doi.org/10.2307/3053513 [Accessed 1 March 2021].

Menkel-Meadow, C., 1984. Toward another view of legal negotiation: The structure of problem-solving. UCLA Law Review, 31, 754-842.

Merry, S.E., 1990. Getting Justice and Getting Even: Legal Consciousness among WorkingClass Americans. University of Chicago Press.

Miller, R.E., and Sarat, A., 1981. Grievances, claims, and disputes: Assessing the adversary culture. Law and Society Review [online], 15(3-4), 525-565. Available from: https://doi.org/10.2307/3053502 [Accessed 1 March 2021].

Moustafa, T., and Ginsburg, T., 2008. Introduction: The functions of courts in authoritarian politics. In: T. Ginsburg and T. Moustafa, eds., Rule by Law: The Politics of Courts in Authoritarian Regimes. Cambridge University Press.

Munger, F., 1988. Tort litigation and social change: accidents and trial court litigation in West Virginia, 1870-1940. Buffalo Law Review [online], 36, 301. Available from: https://digitalcommons.nyls.edu/cgi/viewcontent.cgi?article=1716\&context=fac ar ticles chapters [Accessed 1 March 2021].

Munger, F., ed., 1990. Special Issue: Longitudinal Studies of Trial Courts. Law and Society Review [online], 24(2). Available from: https://www.jstor.org/stable/i354551 [Accessed 1 March 2021].

Murayama, M., 2012, Reconsidering the Japanese way of dispute resolution: What it is and why. In: H.N. Scheiber and T. Ginsburg, eds., Japanese Legal System: An Era of Transition. Berkeley: University of California Press, 66-87.

Nader, L., 1969 Styles of Court Procedure: To make the balance. In: L. Nader, ed., Law in Culture and Society. Chicago: Aldine.

Nader, L., and Todd, H.F., eds., 1978. The Disputing Process: Law in Ten Societies. New York: Columbia Press.

Peel, P., 2017. Renewing the longitudinal study of trial courts. Justice Systems Journal [online], 38(3), 290-305. Available from: https://doi.org/10.1080/0098261X.2017.1306816 [Accessed 1 March 2021].

PON staff, 2019. What is the Multi-Door Courthouse Concept. Program on negotiation, Harvard Law School [online], 22 August. Blog post. Available from: 
https://www.pon.harvard.edu/daily/international-negotiation-daily/a-discussionwith-frank-sander-about-the-multi-door-courthouse/ [Accessed 1 March 2021].

Reed, D.S., 2001. On Equal Terms: The Constitutional Politics of Educational Opportunity. Princeton University Press.

Rosenberg, G.N., 1991. The Hollow Hope: Can Courts Bring About Social Change? University of Chicago Press.

Santos, B.S., 1977. The law of the oppressed: The construction and reproduction of legality in Pasargada. Law \& Society Review [online], 12, 5-126. Available from: https://doi.org/10.2307/3053321 [Accessed 1 March 2021].

Sarat, A., and Grossman, J., 1975. Courts and conflict resolution: Problems in the mobilization of adjudication. American Political Science Review [online], 69, 1200. Available from: https://doi.org/10.2307/1955281 [Accessed 1 March 2021].

Sarat, A., and Scheingold, S., eds., 1998. Cause Lawyering. Oxford University Press.

Shapiro, M., 1980. Courts: A Comparative and Political Analysis. University of Chicago Press.

Shapiro, M., 1993. The globalization of law. Indiana Journal of Global Legal Studies, 1(1), $37-64$.

Skogan, W., 1984. Reporting crime to the police: the status of world research. Journal of Research on Crime and Delinquency [online], 2, 113-137. Available from: https://doi.org/10.1177/0022427884021002003 [Accessed 1 March 2021].

Stone, D., 2020. Counting: How We Use Numbers to Decide What Matters. New York: Livewright.

Toharia, J.J., 1974. Cambio social y vida jurídica en España. Madrid: Edicusa.

van Loon, F., and Langerwerf, E., 1990. Socioeconomic development and the evolution of litigation rates of civil courts in Belgium, 1835-1980. Law and Society Review [online], 24(2), 283-298. Available from: https://doi.org/10.2307/3053679 [Accessed 1 March 2021].

Vidmar, N., and Schuller, R.A., 1987. Individual differences and the pursuit of legal rights. Law and Human Behavior, 11, 299-317.

Vose, C., 1959. Caucasians Only: The Supreme Court, the NAACP, and the Restrictive Covenant Cases. Berkeley: University of California Press.

Wilson, J.Q., 1968. Varieties of Police Behavior. Cambridge, MA: Harvard University Press.

Wollschläger, C., 1990. Civil litigation and modernization: The work of the municipal courts of Bremen, Germany, in five centuries, 1549-1984. Law and Society Review [online], 24(2), 261-282. Available from: https://doi.org/10.2307/3053678 [Accessed 1 March 2021].

Yngvesson, B., 1985. Re-examining continuing relations and the law. Wisconsin Law Review, 1985(3), 623-646. 
Yngvesson, B., 1993. Virtuous Citizens, Disruptive Subjects: Order and Complaint in a New England Court. New York: Routledge.

Yngvesson, B., and Mather, L. 1983. Courts, moots and the disputing process, In: K.O.

Boyum and L. Mather, eds., Empirical Theories About Courts. New York: Longman, 51-83.

Zemans, F., 1983. The neglected role of law in the political system. American Political Science Review, 77(3), 690-703.

Case law

Bristol-Meyer Squibb Co. v Superior Court of California, 137 S. Ct. 1773 (2017).

DeFunis v Odegaard, 416 US 312 (1974).

Lilly Ledbetter v. Goodyear Tire \& Rubber Co., 550 U.S. 618 (2007).

Roe v Wade, 410 U.S. 113 (1973).

Wal-Mart v Dukes, 564 U.S. 338 (2011). 